\title{
Carbamate group as structural motif in drugs: a review of carbamate derivatives used as therapeutic agents
}

\author{
Ana Matošević and Anita Bosak \\ Institute for Medical Research and Occupational Health, Zagreb, Croatia \\ [Received in July 2020; Similarity Check in July 2020; Accepted in December 2020]
}

\begin{abstract}
Due to their very good chemical and proteolytic stability, ability to penetrate cell membranes, and resemblance to a peptide bond, carbamate derivatives have received much attention in recent years and got an important role in modern drug discovery and medicinal chemistry. Today, carbamates make structural and/or functional part of many drugs and prodrugs approved and marketed for the treatment of various diseases such as cancer, epilepsy, hepatitis C, HIV infection, and Alzheimer's disease. In drugs they can play a role in drug-target interaction or improve the biological activity of parent molecules. In prodrugs they are mainly used to delay first-pass metabolism and enhance the bioavailability and effectiveness of compounds. This brief review takes a look at the properties and use of carbamates in various fields of medicine and provides quick insights into the mechanisms of action for some of them.
\end{abstract}

KEY WORDS: anticonvulsants; antiepileptics; cholinesterase inhibitors; neurodegenerative diseases; prodrugs; protease inhibitors

Carbamates are derivatives of carbamic acid, whose amino and carboxyl termini are substituted by a variety of structurally diverse alkyl, aryl, or alkyl-aryl substituents and are identified by the presence of the -O-CO-NH- linkage (1). Carbamates are integral part of many drugs and prodrugs approved by the US Food and Drug Administration (FDA) and the European Medicines Agency (EMA). Many compounds that contain a carbamate group are currently in various stages of preclinical and clinical trials $(1,2)$. An example of a carbamate compound recently approved by the FDA is cenobamate (3), indicated for the treatment of partial-onset seizures in adults (4).

The research of carbamates as potential drugs began with the discovery of physostigmine, a methyl carbamate ester isolated in pure form from the seeds of Calabar beans (Physostigma venenosum) in 1864 (5). Initially, physostigmine was used to treat high eye pressure and glaucoma, but today, it is also used to treat delayed gastric emptying and myasthenia gravis $(5,6)$. Broader utilisation of carbamate compounds began in 1959, when carbaryl was registered as first carbamate pesticide for use in the USA (5). Today, carbamate compounds are widely used as pesticides (insecticides, fungicides, and herbicides), as starting materials in the production of paints and polyurethanes, and as protecting groups of amines in organic synthesis (7).

Studies have shown that the carbamate group increases the biological activity of active pharmacophores of structurally different natural or synthesised compounds $(7$,

Corresponding author: Anita Bosak, Institute for Medical Research and Occupational Health Ksaverska cesta 2, 10000 Zagreb, Croatia E-mail:abosak@imi.hr
8). By varying the substituents at the amino and carboxyl termini of the carbamate group, it is possible to modulate their biological and pharmacokinetic properties and improve their stability $(7,8)$.

The chemical properties of carbamates, their conformational and metabolic stability, the ability to pass through cell membranes, and some through the blood-brain barrier, have made the carbamate group a desirable part of the structure of many pharmacologically important compounds and a structural motif of many drugs and prodrugs.

Moreover, strong growth of carbamate use in the pharmaceutical industry is additionally boosted by the fact that the carbamate group can be considered a structural analogue of the amide bond (8-10). Amide-based molecules make a very good starting point for developing many drugs, enzyme inhibitors in particular. However, their inadequate pharmacokinetic properties, most notably poor in vivo stability and low bioavailability, limit their broader use and development. These limitations of amide-based compounds have recently been addressed by the use of carbamates as amido- or peptidomimetics to improve drug potency, duration of action, or target specificity $(2,9-11)$.

Today, the carbamate group makes part of many approved drugs which act as chemotherapeutic agents (mitomycin C, irinotecan), cholinesterase inhibitors in the treatment of neurodegenerative disorders (rivastigmine, neostigmine, physostigmine, pyridostigmine), human immunodeficiency virus (HIV) protease inhibitors (ritonavir, amprenavir, atazanavir, darunavir), anticonvulsants (felbamate, retigabine, cenobamate), anthelmintics (febendazole, albendazole, 


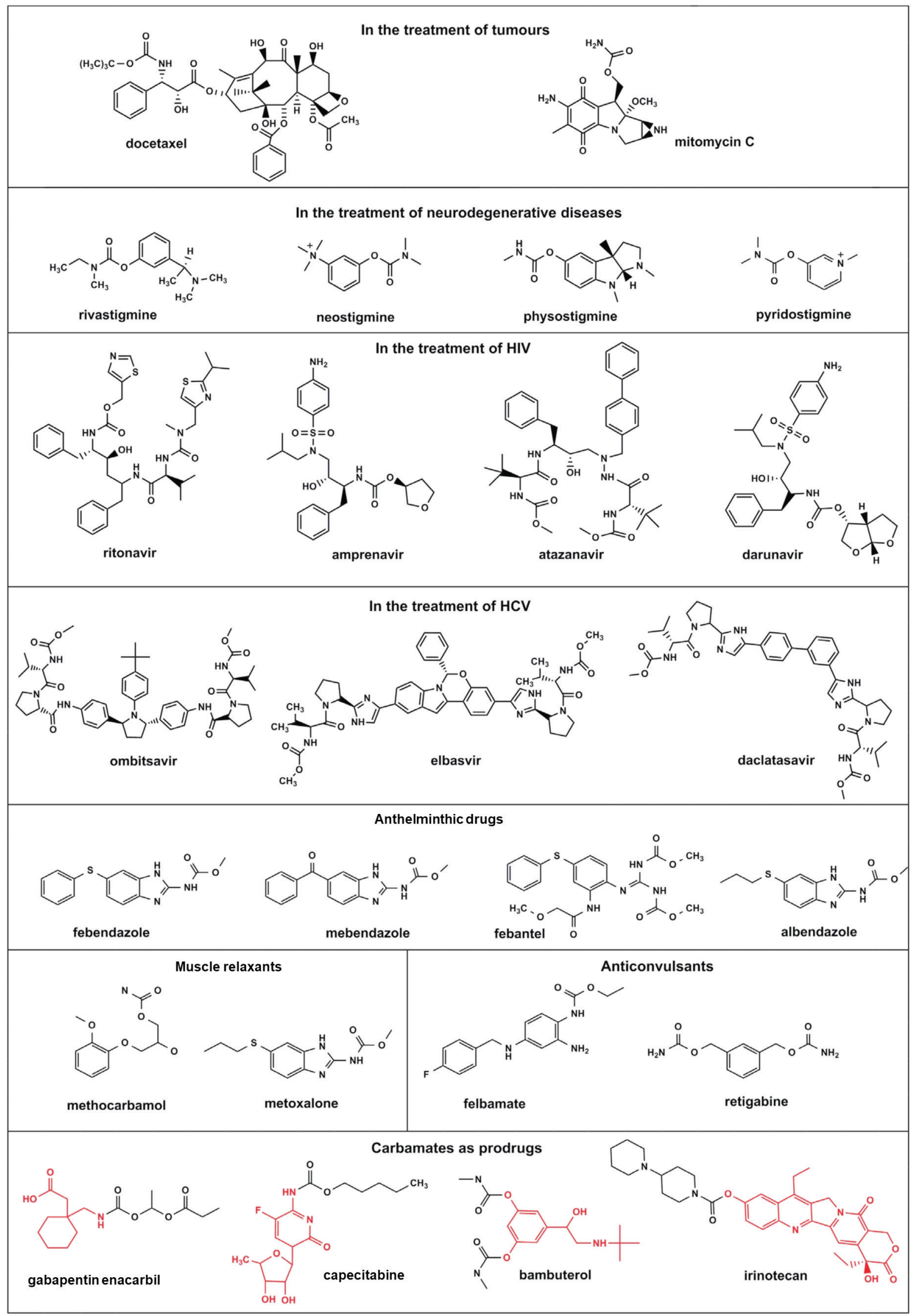

Figure 1 Structures of carbamate-based drugs and prodrugs of different application (carbamate group is presented in blue; active substance of prodrugs is presented in red) 
febantelmebendazole), and muscle relaxants (methocarbamol, metoxalone) (Figure 1). They also make part of prodrugs with different therapeutic applications (irinotecan, bambuterol, gabapentin encabril, capecitabine) $(2,7,12)$ (Figure 1).

The aim of this review is to take a brief look at carbamate proprieties that make them useful in drug design, discuss some of the carbamate-based drugs and prodrugs, and explain the mechanisms of action for some of them.

\section{CARBAMATE PROPERTIES AND APPLICATIONS}

\section{Chemical properties of carbamates}

The structure of biologically active carbamates is shown in Figure 2. The carbamate group consists of a carbonyl group $(\mathrm{C}=\mathrm{O})$ to which an alkoxyl group $\left(\mathrm{OR}^{1}\right.$ in Figure 2, marked blue) and an amino group $\left(\mathrm{R}^{2} \mathrm{NR}^{3}\right.$ in Figure 2, marked red) are attached. $\mathrm{R}^{1}, \mathrm{R}^{2}$, and $\mathrm{R}^{3}$ may be different alkyl, aryl, and alkyl-aryl or substituted alkyl, aryl, and alkyl-aryl groups $(2,7)$. Replacing the carbonyl oxygen atom with sulphur generates thiocarbamates, while additional replacement of the alkoxy oxygen with a sulphur atom generates dithiocarbamates (2).

The carbamate group owes its functionality to the structural similarity between amides $\left(\mathrm{R}^{2} \mathrm{NR}^{3}-\mathrm{CO}-\mathrm{R}^{1}\right)$ and carbamates. Namely, carbamates can be structurally considered as "amide-ester" hybrids with chemical reactivity comparable to these two functional groups. Due to this amide-ester combination, carbamates are chemically stable and able to modify inter- and intramolecular interactions (13).

Carbamate stability stems from the resonance between the amide and carboxyl group, which has been studied theoretically and experimentally by estimating the C-N bond rotational barriers (14). Figure 2 shows three resonance structures obtained from carbamate group stabilisation. The carbamate rotational barrier of the C-N bond is about 3-4 kcal/mol (15-20\%) lower than the rotational barrier of structurally analogue amides due to steric and electron perturbations which result from the presence of additional oxygen of the carboxyl group (14-16) and which make carbamates more electrophilic than amides and sufficiently reactive to spontaneously react with nucleophiles (9).

Another important feature of carbamates is their conformation. Due to a pseudo double bond in their structure, carbamate molecules can exist as cis and trans isomers (Figure 3) $(17,18)$, but they show no preference for either isomeric form, as the difference in free energy of the isomers is small, about $1-1.5 \mathrm{kcal} / \mathrm{mol}$ due to the steric and electrostatic properties of the substituents.

However, this difference in free energy and consequently the ratio of the two conformations can change with conditions like type and/or composition of the solvents, concentration of salts, and $\mathrm{pH}$ of the reaction mixture (17, 18). For example, decreasing the $\mathrm{pH}$ of a reaction mixture in which amino acids are protected by the tert-butyl carbamate $(B O c)$ group, increases the concentration of $c i s$ isomers, while increasing the temperature increases the concentration of trans isomers (19). One study (20) which used a carbamate group to connect different ammonium groups to the entrance of the gramicidin ion channel, demonstrated that the ratio of cis/trans isomers depended on combined electrostatic and steric effects of the carbamate linker on cation flux through the channel. This suggests that a compound able to change the carbamate cis/trans ratio may also be used to regulate ion channel flux (13). R and $\mathrm{R}^{1}$ (Figure 3) substituents must also be taken into account, as the steric effects of $\mathrm{R}$ and electronegativity of $\mathrm{R}^{1}$ influence the difference in free energy and therefore the $c i s$ / trans ratio.

Five-, six-, and seven-membered cyclic carbamates can only exist as trans conformers. Five- or six-membered carbamates are quite stable because they generally do not undergo metabolic ring opening (17).

Furthermore, carbamates are semi-polar compounds that can form hydrogen bonds, both as hydrogen donors and as hydrogen acceptors, and various interactions can take place at their $\mathrm{O}-$ and $\mathrm{N}$-termini. Carbamates contain $\mathrm{C}=\mathrm{O}$ and $\mathrm{N}-\mathrm{C}$ dipoles arising from covalent bonding of electronegative oxygen and nitrogen atoms with electroneutral carbon atoms. Because of the $\pi$-bonding arrangement of carbonyl and greater electronegativity of oxygen, carbonyl is a stronger dipole than the N-C dipole. The presence of a $\mathrm{C}=\mathrm{O}$ dipole allows carbamates to act as $\mathrm{H}$-bond acceptors, whereas the $\mathrm{N}-\mathrm{C}$ dipole allows them to act as H-bond donors, but to a lesser extent (9).

Unlike amides, carbamates are proteolytically stable against various proteases (9), and can even inhibit them as discussed later. Thanks to these properties - proteolytic, chemical, and conformational stability and ability to pass through the cell membrane and blood brain barriers (not all) - carbamates are increasingly replacing peptides in pharmaceuticals (7).

Their pharmacological activity mostly depends on the speed and intensity of their hydrolysis (21), and their major hydrolysis pathway in physiological conditions is base hydrolysis. The mechanisms of base hydrolysis of monosubstituted and disubstituted carbamates are shown in Figure 4 (22). The difference between these two mechanisms is in the intermediate, which is an isocyanate anion in monosubstituted carbamates and a carbonate anion in disubstituted carbamates. Following basic hydrolysis, parent alcohol and carbamic acid are released, and carbamic acid rapidly decomposes to the corresponding amine and carbon dioxide $(21,22)$. Carbamate derivatives could be used as prodrugs for amines or alcohols and phenols to delay first-pass metabolism and enhance hydrolytic stability of compounds (23). 


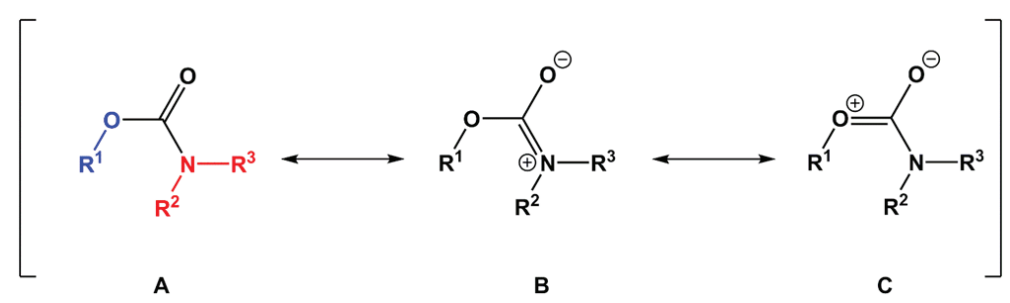

Figure 2 Possible resonance structures for the carbamate group (amino group is presented in red, and alkoxy group in blue) (adopted from ref. 14)

A recent review by Vacondio et al. (21) has compiled substantial data from recent studies of metabolic stability of therapeutic carbamates to evaluate the qualitative relationship between molecular structure of carbamates and their susceptibility to metabolic hydrolysis and has proposed the following order in metabolic resistance: aryl-OCONHalkyl > > alkyl-OCO-NHalkyl alkyl-OCO-N(alkyl) ${ }_{2} \geq$ alkyl-OCO-N(endocyclic) $\geq$ aryl-OCO-N(alkyl $)_{2} \sim$ arylOCO-N(endocyclic) $\geq$ alkyl-OCONHAryl $\sim$ alkyl-OCONHacyl $>>$ alkyl-OCO-NH2 > cylclic carbamates (21).<smiles>[R16]NC(=O)O[R]</smiles><smiles>[R]NC(=O)O[R]</smiles>

Figure 3 Cis and trans conformations of carbamates (adopted from ref. 14)

\section{Application of carbamates}

Carbamate derivatives have a wide range of applications. Their first massive use in agriculture as pesticides, fungicides, and insecticides in various crops all around the world started in the 1950s (25-27). They have been the second most common pesticides and a welcome replacement of poisonous organochloride pesticides since the 1970s. Even so, some of them are assumed to be potentially carcinogenic and mutagenic or display acute toxicity for mammals and aquatic organisms (28-30). Most carbamates used in agriculture represent an issue for the environment with more than 10,000 tonnes deployed each year, which makes their clean-up one of environmental priorities (30).

Mass use of carbamates in everyday life was expanded by the discovery of polyurethanes (PUs) - compounds with polymerised carbamate groups whose biological, chemical, and physical properties enabled carbamate application in surface coatings, synthetic fibres, elastomers, foams, and packaging (31). It must be mentioned that ethyl carbamate, also known as urethane, has no connection with polyurethanes in any way. Urethanes are commonly synthesised from an alcohol and an isocyanate, while carbamate synthesis usually does not involve isocyanate as reactant (32).

Carbamates are also used to protect amino groups, most notably tert-butoxycarbonyl $(B o c)$, benzyloxycarbonyl
(Cbz), and allyloxycarbonyl (Alloc) (33). As starting material, carbamates have also a leading role in the paint industry $(8,34)$.

In recent years, carbamate derivatives, including urethanes (especially five- or six-membered cyclic and bicyclic fused carbamates) have seen an expansion to pharmaceutical industry as important structural and functional elements in the design of drugs and prodrugs $(32,35)$.

\section{CARBAMATES AS DRUGS}

The biological activity of a carbamate was first reported by European missionaries in West Africa in the $19^{\text {th }}$ century. There a local tribe was using a white extract from Calabar beans (Physostigma venenosum) as an ordeal poison in witchcraft trials (36). These beans were imported to Great Britain in 1840, and in 1864, Jobst and Hesse isolated an active alkaloid component they named physostigmine (37). Physostigmine is a naturally occurring methyl carbamate ester initially used as a medicine to treat glaucoma, but its application broadened over the years. Physostigmine was reported to markedly improve muscle strength in patients with myasthenia gravis and had been the drug of choice for this condition for three decades, until it was replaced by a longer-acting oral agent pyridostigmine. Today, physostigmine is also used to treat delayed gastric emptying and anticholinergic poisoning caused by overdosing with atropine, scopolamine, and other anticholinergic drugs. Furthermore, pyridostigmine seems to improve long-term memory, which is why it was clinically studied for treatment of Alzheimer's disease but was abandoned due to moderate to severe side effects in favour of other acetylcholinesterase inhibitors $(38,39)$.

Because of their chemical and proteolytic stability, ability to create inter- and intramolecular interactions, and bond resembling that of amides, carbamates soon piqued the interest of pharmaceutical industry $(2,7,9)$. Recent studies $(2,8)$ have shown that incorporating the carbamate group in a molecule increases the biological activity of active pharmacophores of structurally different natural or synthesised compounds. For example, replacing the unsaturated ester chain at C-6 in fumagillin (a natural antibiotic and endothelial cell proliferation inhibitor) with the $O$-(chloroacetyl) carbamoyl moiety resulted in a 50 
Table 1 Roles of the carbamate moiety in drugs and prodrugs

\begin{tabular}{|c|c|c|}
\hline Drug & The role of the carbamate moiety in the drug & Reference \\
\hline Docetaxel & $\begin{array}{l}\text { prolongs drug action, increases drug potency, } \\
\text { improves water solubility }\end{array}$ & 39 \\
\hline Mytomicin C & $\begin{array}{l}\text { participates in the formation of an alkylating compound during } \\
\text { reaction with target }\end{array}$ & 40 \\
\hline $\begin{array}{l}\text { Rivastigmine, neostigmine, } \\
\text { physostigmine, pyridostigmine }\end{array}$ & key element for interaction with the target & 38 \\
\hline $\begin{array}{l}\text { Ritonavir, amprenavir, atazanavir, } \\
\text { darunavir }\end{array}$ & $\begin{array}{l}\text { improves drug bioavailability and potency, engaged in a } \\
\text { backbone interaction with protease }\end{array}$ & 8 \\
\hline Ombitasvir, elbasvir, daclatasavir & improves drug stability and lipophilicity & 41 \\
\hline $\begin{array}{l}\text { Febendazole, mebendazole, febantel, } \\
\text { albendazole }\end{array}$ & $\begin{array}{l}\text { improves aqueous solubility and bioavailability, } \\
\text { increases cytotoxicity }\end{array}$ & 42 \\
\hline Mehocarabamol, metaxalone & $\begin{array}{l}\text { inhibits acetylcholinesterase at synapses in the autonomic nervous } \\
\text { system, neuromuscular junction, and central nervous system }\end{array}$ & 43 \\
\hline Felbamate & improves drug stability and bioavailability & 44,45 \\
\hline Retigabine & $\begin{array}{l}\text { major pharmacophore responsible for interacting with residues } \\
\text { in the KCNQ2-5 channels }\end{array}$ & 46 \\
\hline Gabapentin enacarbil & improves bioavailability & 47 \\
\hline Capecitabine & improves selectivity and bioavailability & 47 \\
\hline Bambuterol & delays first-pass metabolism & 47 \\
\hline Irinotecan & improves aqueous solubility & 47 \\
\hline
\end{tabular}

times more potent antitumor compound. Another example is betulinic acid, a very promising anticancer drug (8), whose imidazole and triazole carbamate derivatives were 12 times more potent and less cytotoxic (2). This possibility to change the biological and pharmacokinetic properties and improve the stability of parent compounds by varying the substituents on the $O$ - and/or $N$ - termini of a carbamate group has recently boosted the interest in developing efficient and safe synthesis of carbamate esters (8). Today, many drugs incorporate the carbamate moiety, whose roles in some drugs and prodrugs are listed in Table 1.

\section{Carbamates in tumour treatment}

Two carbamate drugs, mitomycin $\mathrm{C}$ and docetaxel, have so far been approved for the treatment of various types of tumours (Figure 1). Both can be used alone or in combination to other antitumor drugs (48-50). Their antitumor activity stems from their ability to selectively inhibit the synthesis of DNA in a tumour cell or to inhibit the tubulin polymerisation, both resulting in the arrest of mitotic phase of cell division (48).

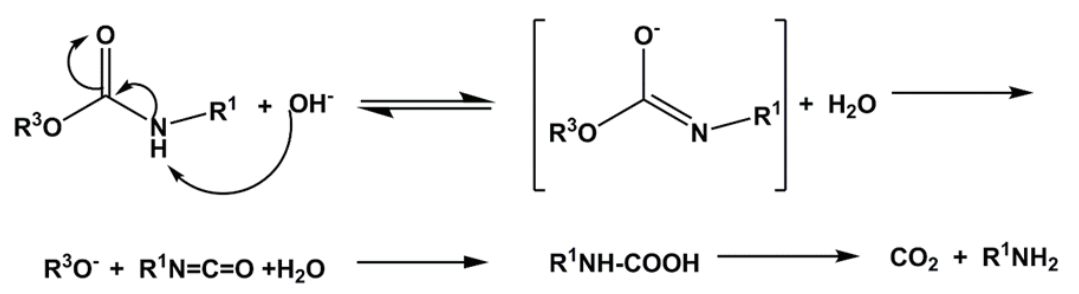

Alkaline hydrolysis of monosubstituted carbamates

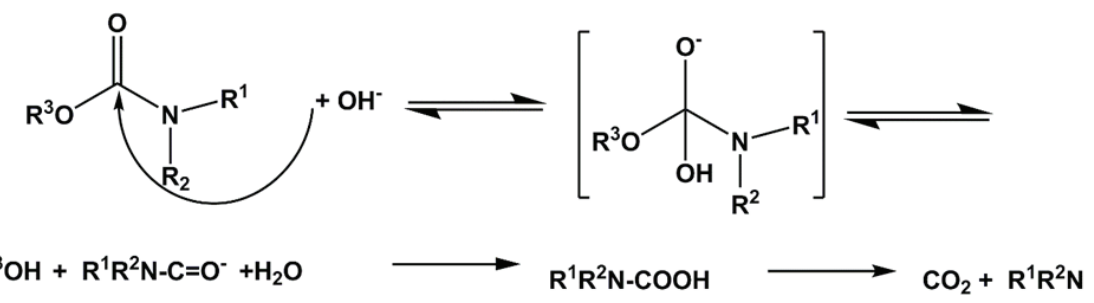

Alkaline hydrolysis of disubstituted carbamates

Figure 4 Alkaline hydrolysis of monosubstituted (A) and disubstituted (B) carbamates (adopted from ref. 22) 


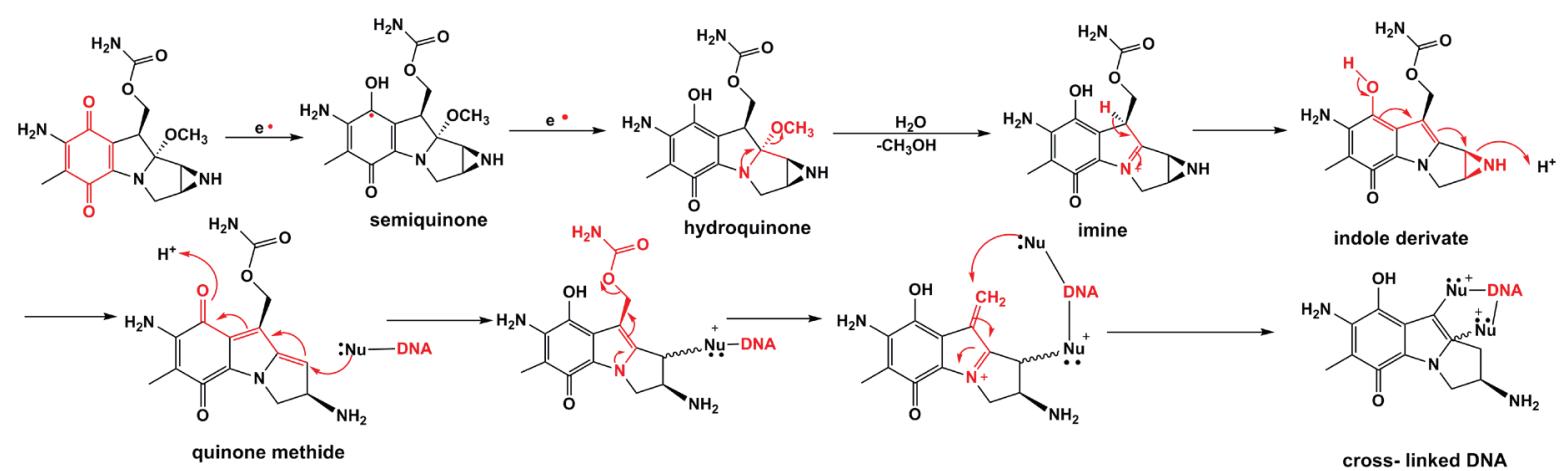

Figure 5 Mechanism of action of mitomycin C (adopted from ref. 40)

Mitomycin $\mathrm{C}$ is a miscellaneous antibiotic that selectively inhibits DNA synthesis in a tumour cell and is indicated for chemotherapy of gastrointestinal, anal, and breast cancers (49). Its mechanism of action is given in detail in Figure 5 (40). All starts with an in situ bioreductive activation of quinone that involves two consecutive reduction steps to the corresponding hydroquinone. The elimination of methanol from hydroquinone produces a reactive imine. Deprotonation of imine results in an indole derivative that undergoes rearrangement to produce a quinone methide, which then reacts with nucleophilic DNA groups, yielding an unstable intermediate that binds to complementary strands of double-stranded DNA coils. This binding inhibits DNA replication and causes tumour cell death. At high concentrations, mitomycin $\mathrm{C}$ has also been shown to suppress RNA and protein synthesis, inhibit proliferation of B-cells, T-cells, and macrophages in vitro, and to reduce the secretion of interferon gamma, tumour necrosis factor alpha (TNF $\alpha$ ), and interleukin 2 (IL-2) (40, 51).

Docetaxel (Figure 1) is a chemotherapeutic used to treat breast, head/neck, stomach, prostate, and lung cancers. It binds to the $\beta$-subunit of tubulin and forms the docetaxel- tubulin complex, which interferes with tubulin polymerisation and, in turn, leads to tumour cell cycle arrest and apoptosis, including the apoptosis of B-cells affected by leukaemia $(50,52)$.

\section{Carbamates in HIV infection treatment}

HIV-1 protease is essential for viral maturation, as it cleaves newly synthesised polyproteins Gag and Gag-Po to create mature protein components of the HIV virion, the infectious form of the virus outside the host cell (53). There are ten HIV protease inhibitors approved by the FDA, four of which have the carbamate group in their structure (ritonavir, atazanavir, amprenavir, and darunavir). These bind directly to the active site of HIV-1 protease to prevent Gag and Gag-Po cleavage (53-58). One of them, ritonavir, was later found that not only it inhibits HIV protease but can also boost blood concentrations of other HIV protease inhibitors by inhibiting cytochrome P450 3A4, which would otherwise metabolise them and render inefficient (54-56). Another HIV protease inhibitor, atazanavir, shows good oral bioavailability allowing a once-a-day dosing. It is used only in combination with ritonavir and/or other antiviral

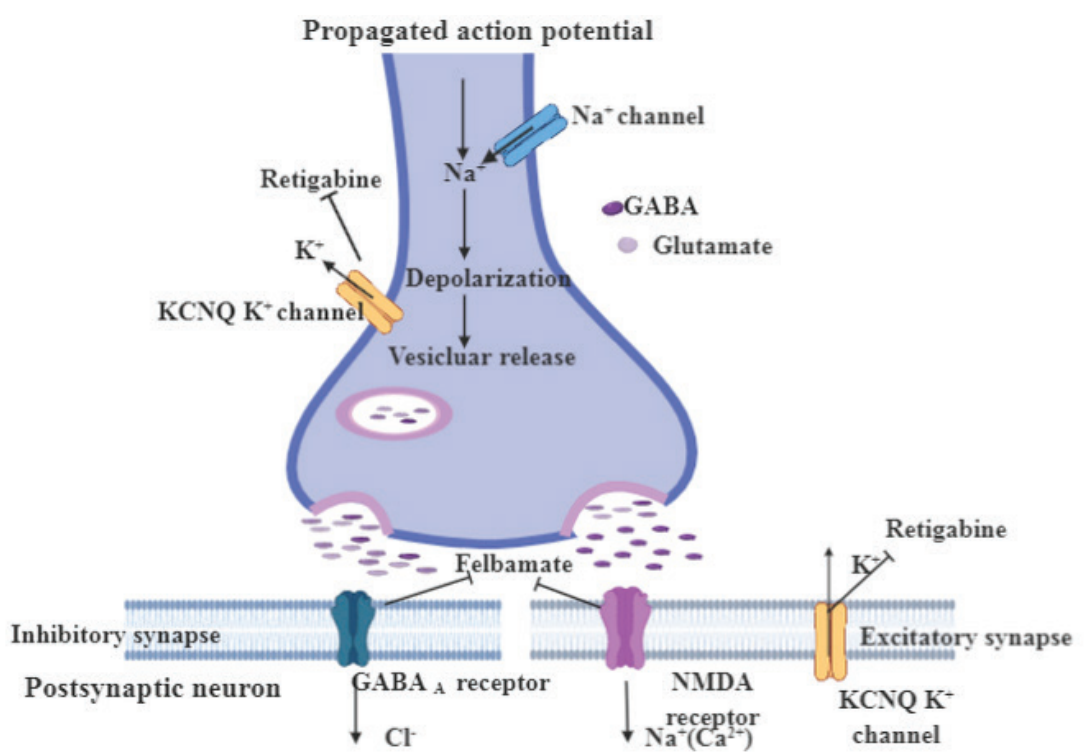

Figure 6 Proposed targets and mechanism of action of felbamate and retigabine in postsynaptic neuron (adopted from refs. 62 and 63 ) 
drugs $(55,56)$ and as such currently makes the first-line antiretroviral treatment $(56,57)$.

\section{Carbamates as antiepileptics and anticonvulsants}

Carbamate anticonvulsants used in epilepsy treatment are felbamate and retigabine (Figure 1). Their exact mechanism of action is still unclear but what is known is that they inhibit $N$-methyl-D-aspartate (NMDA) receptors to some extent and slightly enhance gamma-aminobutyric acid (GABA) activity $(59,60)$.

Felbamate is potent and very effective anticonvulsant approved by FDA in 1993 for the management of focal seizures and Lennox-Gastaut syndrome. It is effective as monotherapy or add-on to phenytoin and carbamazepine in patients with uncontrolled focal epilepsy $(61,62)$. However, its approval has now been limited because its use is associated with the development of aplastic anaemia and hepatic failure. It is now available in the USA only for a very limited use, principally by neurologists in patients for whom potential benefit outweighs the risk (60). It is believed that felbamate acts as NMDA receptor-ionophore complex antagonist at the strychnine-insensitive glycine-recognition site (62), as it blocks the effects of excitatory amino acids, suppresses neuronal firing, and prevents seizure. As for GABA receptors, some studies suggest that felbamate weakly inhibits $\mathrm{GABA}_{\mathrm{A}}$-receptor binding sites and thus enhances GABA-elicited $\mathrm{Cl}^{-}$currents in cultured cortical neurons. This may explain how felbamate dampens neuronal excitation and inhibits voltage-gated sodium and calcium channels (Figure 6) producing a barbiturate-like effect $(63,64)$. However, one in vitro receptor-binding study reported that felbamate did not enhance GABA evoked ${ }^{36} \mathrm{Cl}^{-}$influx in cultured spinal cord neurons (65). These discrepancies between reports may lie in varying regional and ontogenetic expression of GABA receptor subunits and varying properties of GABA receptors between central nervous system (CNS) regions and stages of development (66).

Retigabine is an anticonvulsant used as adjunct in the treatment of partial seizures in adult patients, tinnitus, migraine, and neuropathic pain $(45,46,67)$. The mechanism of its action is unique among antiepileptic drugs and represents a new approach in the treatment of neurological conditions. Retigabine works primarily by opening a particular group of voltage-regulated potassium ion channels in brain cells - KCNQ2 and KCNQ3 (Figure 6) - which stabilises the resting membrane potential and regulates electrical neuron excitation to keep it below the threshold. This prevents the onset of epileptiform discharges $(46,67,68)$.

Cenobamate is indicated for the treatment of partialonset seizures in adults $(3,4)$. It selectively blocks the persistent sodium current of voltage-gated sodium channels (VGSCs) $(3,4)$. It also acts as a positive allosteric modulator of high-affinity GABA $\mathrm{A}_{\mathrm{A}}$ receptors to stabilise neural circuits of the epileptic hippocampus (69).

\section{Carbamates in the treatment of neurodegenerative diseases}

Neurodegenerative diseases are characterised by progressive structural and functional degeneration of the central and/or peripheral nervous system (70). One of their

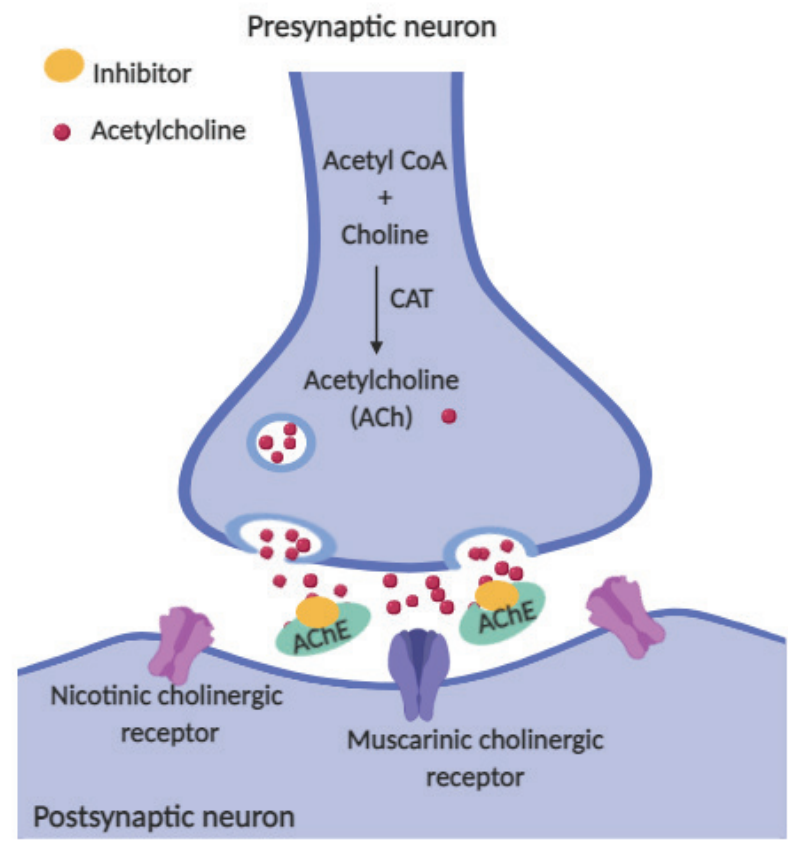

Figure $7 \mathrm{~A}$ proposed simplified mechanism for AChE inhibition by carbamates. Rapid formation of the covalent enzyme-carbamate intermediates, followed by slow regeneration of a free $\mathrm{AChE}$ prevents breaking down of acetylcholine in postsynaptic cleft by $\mathrm{AChE}$ (adopted from ref. 81) 
clinical manifestations is the depletion of acetylcholine (ACh), a neurotransmitter in cholinergic synapses, caused by its excessive metabolism to choline and acetic acid mediated by cholinesterases. In humans, there are two cholinesterases: acetylcholinesterase (AChE), whose physiological role is to hydrolyse $\mathrm{ACh}$, and butyrylcholinesterase (BChE), whose physiological role is still unclear, except that it hydrolyses ACh and other esters and scavenges some toxins by reacting with them before they reach AChE (70-72). Treatment of patients with neurodegenerative diseases who have low ACh levels (Alzheimer's disease) and disorders of the neuromuscular system (Parkinson's disease, myasthenia gravis) is focused on alleviating symptoms. Restoring the concentration of ACh by inhibiting AChE (Figure 7) is the primary treatment for cognitive deficits, although more recent studies point to $\mathrm{BChE}$ as a new possible target of cholinesterase inhibitors (73-75). To date, different types of cholinesterase inhibitors have been identified, designed, and synthesised. The first such cholinesterase inhibitor to be clinically approved was a natural carbamate physostigmine (76). Since then, many carbamates have been developed and tested for the treatment of various disorders of cholinergic neurotransmission. Four of them are currently approved for treating neurodegenerative diseases: physostigmine, pyridostigmine, rivastigmine, and neostigmine (Figure 1) (77).

Physostigmine acts by inhibiting AChE activity and preventing ACh hydrolysis, which in turn increases ACh levels at the synapse and indirectly stimulates nicotinic and muscarinic receptors. As it crosses the blood-brain barrier, it can also treat the effects of atropine and other anticholinergic drug overdoses on the CNS $(78,79)$.
Pyridostigmine and neostigmine are parasympathomimetics used in the treatment of myasthenia gravis and both inhibit $\mathrm{AChE}(78,80)$. Rivastigmine inhibits both $\mathrm{AChE}$ and $\mathrm{BChE}$ and is used to treat mild to moderate Alzheimer's and Parkinson's dementia (77).

Cymserine is a physostigmine-based compound with a isopropylphenyl instead of a methyl group at the $N-4$ ' position, which makes it 15 times more selective for $\mathrm{BChE}$ than AChE (81-84). In clinical trials it has shown highly promising results in patients with Alzheimer's disease, but also unacceptable side effects caused by its toxic metabolites (85).

One of the pathological features of Alzheimer's is the formation of $\beta$-amyloid $(A \beta)$ peptides in the cortex of patients with Alzheimer's. A $\beta$-peptides are generated by sequential cleavage of $\beta$-amyloid precursor protein (APP) by $\beta$-secretase and $\gamma$-secretase. These two enzymes have therefore become important targets in designing drugs to treat Alzheimer's disease (8).To overcome the limitations imposed by cymserine metabolite induced side effects in clinical trials, several cymserine derivatives (Figure 8) have been tested in vivo and shown to increase ACh levels in the brain, produce nootropic effects, and reduce APP and A $\beta$ peptide levels. They have the potential to become the first drugs capable of stopping and even reversing the progression of Alzheimer's disease (86).

Many other carbamate compounds have been designed as potential secretase inhibitors, but none have yet been approved for medical use. Some have shown great $\beta$-secretase inhibition potential, like the 16-membered macrocycle (compound A in Figure 9) containing a transolefin, amide, and carbamate functionalities. Others, like

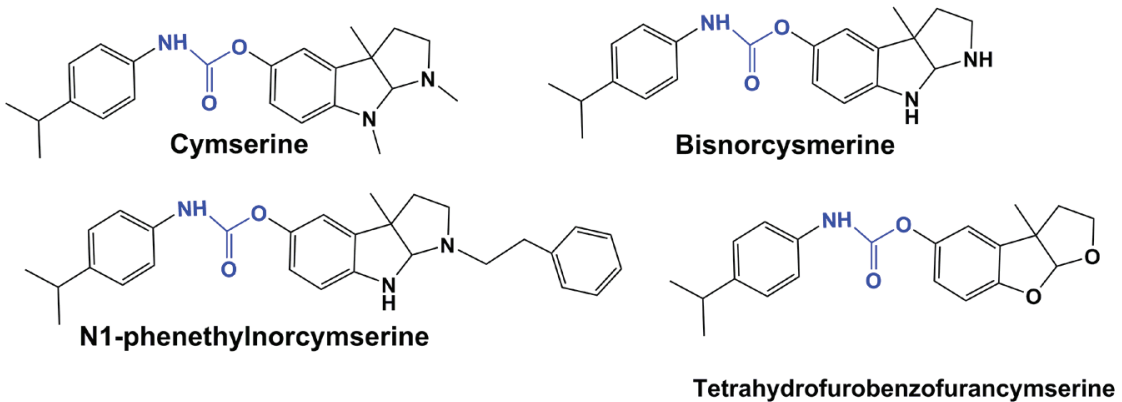

Figure 8 Cymserine and its derivatives (carbamate group in blue) (adopted from ref. 82)<smiles>CC(C)CC(NC(=O)C(CC(=O)NC/C=C/CCCOC(=O)NC(C(=O)NCCc1ccccc1)C(C)C)NC(=O)C(C)C)C(=O)NC(C(=O)NCCc1ccccc1)C(C)C</smiles>

A<smiles>[B]c1ccc(S(=O)(=O)N2C(COC(=O)N3CCC(N4CCCCC4)CC3)CC(O)CC2c2ccccc2)cc1</smiles>

Figure 9 Chemical structure of secretase inhibitors tested with potential to be used in treatment of Alzheimer's disease A-a 16-membered macrocycle compound; B - sulphonamide compound (adopted from ref. 8) 
sulphonamide derivatives (B in Figure 9) have shown strong $\gamma$-secretase inhibition (8).

\section{Carbamates in the treatment of hepatitis $C$}

Hepatitis $\mathrm{C}$ virus (HCV) causes acute and chronic mild to severe hepatitis. With time, a significant number of chronic patients develop cirrhosis or liver cancer (87).

Recent years have seen the development of a number of new and effective hepatitis $\mathrm{C}$ drugs which specifically target viral NS3/4A protease, non-structural protein 5A (NS5A), or NS5A RNA polymerase to inhibit viral replication, and counter NS5A-associated interferon-resistance as the common cause of treatment failure (87-89). Today, there are ten carbamates targeting NS5A. Six have been approved for use (89) and the rest are in phase III of clinical trials $(89,90)$. They inhibit NS5A by blocking signalling interactions, redistributing NS5A from the endoplasmic reticulum to the surface of lipid droplets, and by inhibiting HCV replication $(9,92)$. Figure 1 shows the structures of three approved carbamate HCV inhibitors: daclatasavir, elbasvir, and ombitsavir (93).

Antiviral action is further increased by combining NS5A with NS3/4A protease inhibitors, as is the case with daclatasavir and sofosbuvir (92-95). Both daclatasavir and sofosbuvir and their combination have been included in the WHO model list of the most efficacious, safe, and cost-effective medicines for a specific condition, the so called essential medicines list (EML) (96).

\section{Carbamates as muscle relaxants}

The best known carbamate muscle relaxants are methocarbamol and metaxalon (Figure 1) (43). Although the exact mechanism of action of methocarbamol is still not clarified, it is believed to involve $\mathrm{AChE}$ inhibition at synapses in the autonomic nervous system, neuromuscular junction, and the CNS (97). Metaxalone is usually prescribed as adjuvant therapy that accompanies rest, physical therapy, and other measures to relieve acute musculoskeletal pain. Its mode of action is also not clear, but is most likely related to general CNS depression (98).

\section{Carbamates as anthelmintics}

The carbamates that act against parasitic worms or helminths in humans and animals are fenbendazole, febantel, mebendazole, and albendazole (Figure 1) (99). Mebendazole and albendazole are benzimidazole carbamate anthelmintics used to treat a broad range of parasitic infections $(100,101)$. Their mechanism of action is analogous to that of docetaxel: they selectively inhibit microtubule synthesis by binding to $\beta$-tubulin and blocking the polymerisation of tubulin dimers in intestinal parasite cells. This disruption of cytoplasmic microtubules results in blocking glucose and other nutrient transport in parasites cells and their gradual immobilisation and death (101).

\section{CARBAMATES AS PRODRUGS}

Prodrugs are designed to undergo enzymatic and/or chemical metabolism in the body to release the active drug with a desired pharmacological effect (Figure 10) $(47,102)$. They serve as carriers to overcome physicochemical, biopharmaceutical, or pharmacokinetic limitations of active drugs by increasing their solubility in water and absorption, by delaying their first-pass metabolism, by delivering them to the brain, or by reducing their toxicity and local irritation (103). Prodrugs generally consist of a parent (active) drug and a promoiety that masks the functional group within the parent drug (Figure 10). Typically, a promoiety is attached to the active drug with bond(s) that break in certain conditions, such as the presence of an enzyme or a change in $\mathrm{pH}$ and releasing the active substance to do its job (103). Esters are used as prodrugs to improve lipophilicity and permeability through cell membranes, while phosphate esters, oximes, and amides are used to improve drug solubility in water and oral absorption $(47,103)$.

Carbamates are used in the design of prodrugs of carboxyl, hydroxyl, or amine functionalities to delay firstpass metabolism and enhance systemic hydrolytic stability (103) (Table 1). Their bioconversion for active drug release involves rapid hydrolysis mediated by metabolic enzymes, mainly cytochrome P450 and esterases, which usually occurs in the liver $(22,47,103)$.

\section{Carbamate prodrugs with a phenol as active substance}

Carbamates are used as prodrugs of alcohols and phenols to achieve systemic hydrolytic stability and protection from first-pass metabolism (23). Carbamates of $N$-monosubstituted and $N, N$-disubstituted alcohols are chemically stable against hydrolysis (21), as are the carbamates of $N, N$-disubstituted phenols but not as much those of $N$-monosubstituted phenols $(21,24)$. Examples of carbamate prodrugs whose active substance is alcohol or phenol are irinotecan and bambuterol (Figure 1).
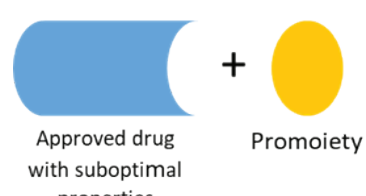

properties

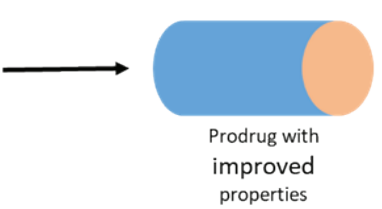

(enzymatic/chemical

biotransformation

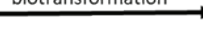

properties

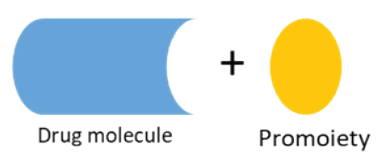

Figure 10 A simplified illustration of the prodrug concept 


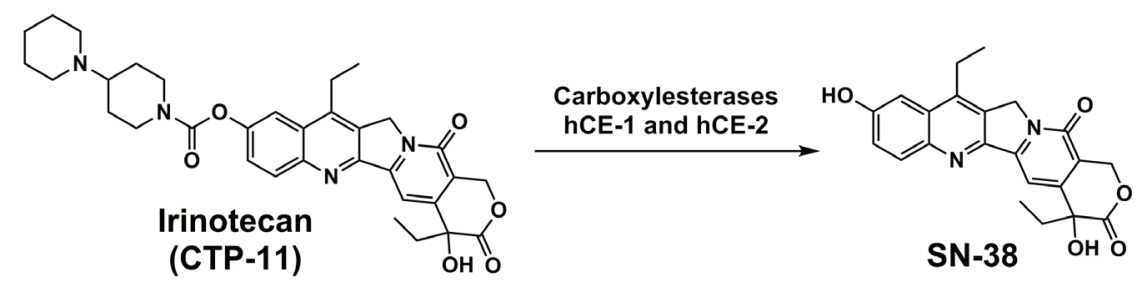

Figure 11 Irinotecan metabolism by carboxylesterases hCE-1 and hCE-2 (adopted from ref. 105)

Irinotecan (CPT-11) is a semisynthetic analogue of the natural alkaloid camptothecin, commonly used for the treatment of colon, rectal, and ovarian cancers $(104,105)$. In human body, irinotecan is metabolised by tissue and serum carboxylesterases to an active compound SN-38 (106), which has a 100-1,000 times higher antitumour activity than irinotecan. SN-38 inhibits topoisomerase I activity by stabilising the cleavable complex between topoisomerase I and DNA, which leads to DNA breaks, inhibition of DNA replication, and triggers apoptotic cell death (Figure 11) (106).

Bambuterol (Figure 1) is a bis-dimethyl carbamate prodrug of terbutaline, used to treat asthma and chronic obstructive pulmonary disease. Bambuterol belongs to long-acting drugs due to catecholic hydroxyl groups in its structure that are quite resistant to hydrolysis and first-pass metabolism. In the lung tissue, bambuterol is hydrolysed to terbutaline by BChE (Figure 12), and in the liver, it is metabolised to terbutaline under the influence of cytochrome P-450-dependent oxidases $(24,107,109)$. Terbutaline is an adrenergic agonist that predominantly stimulates $B-2$ receptors to relax the smooth muscle of the bronchus and dilate the airways (107-109).

\section{Carbamate prodrugs with an amine as active substance}

At physiological $\mathrm{pH}$ amine-based drugs or drugs having an amine group in the structure can undergo protonation and may not always be optimally distributed in the body $(47,102)$. Because of that, polar amino groups are often derivatised to make the compounds neutral or hydrophobic, i.e. more soluble in lipids $(47,102)$. One of the derivatisation strategies involves introduction of carbamate moiety into drug structure. Currently used amine-based carbamate

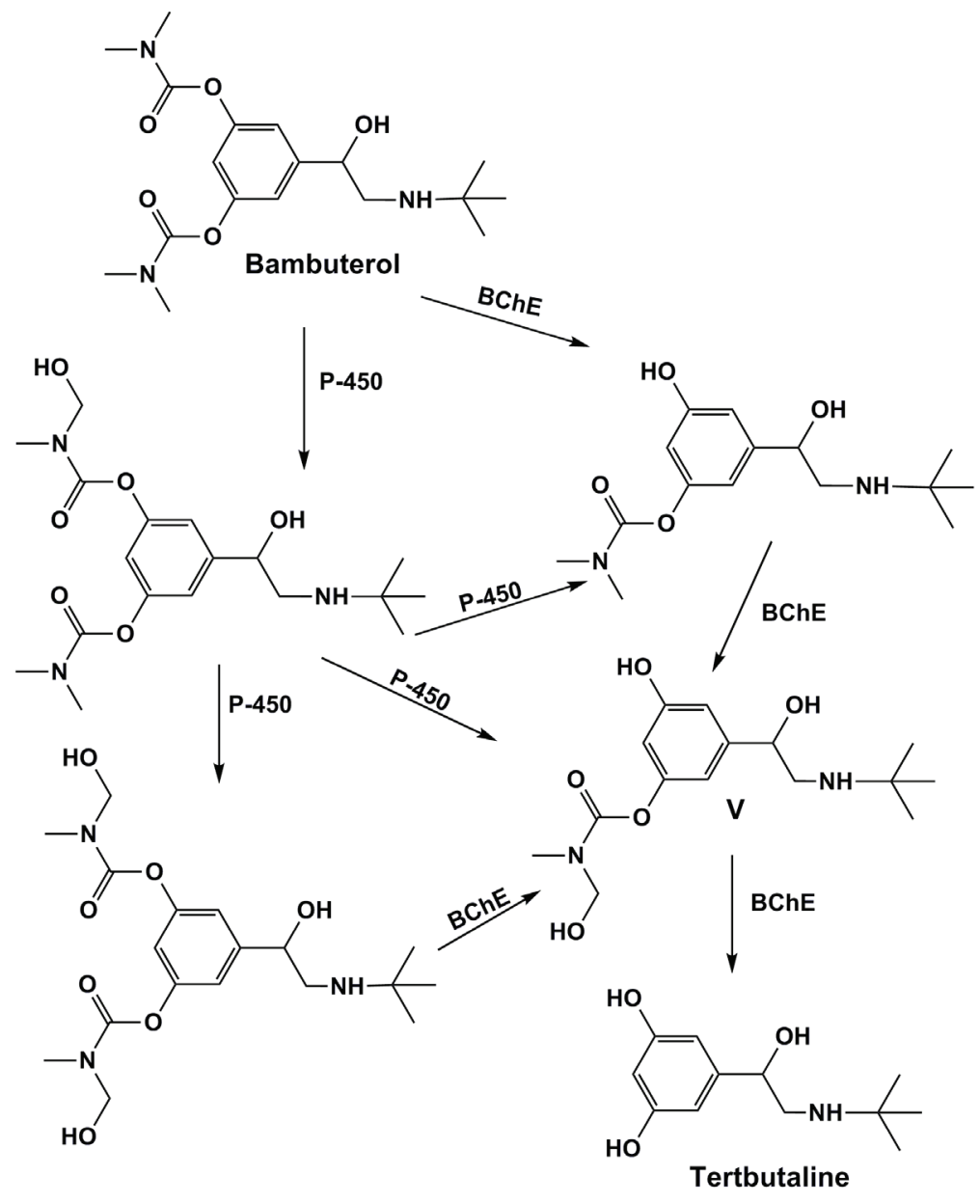

Figure 12 Bambuterol metabolism into tertbutaline by cytochrome p450 and butyrylcholinesterase (BChE) (adopted from ref. 106) 
prodrugs gabapentin enacarbil and capecitabine are presented in Figure 1.

Gabapentin enacarbil is a prodrug designed to increase oral bioavailability of gabapentin used to treat the restless legs syndrome (RLS) and postherpetic neuralgia (PHN) in adults (110). After oral administration gabapentin enacarbil gets strongly hydrolysed by non-specific carboxylesterases, primarily in enterocytes and to a lesser extent in the liver, to form the active drug gabapentin, carbon dioxide, acetaldehyde, and isobutyric acid (110).

Capecitabine is a fluoropyrimidine carbamate of the antimetabolite class of chemotherapeutics (111) that is selectively activated by tumour cells to produce cytotoxic 5-fluorouracil (5-FU) (112), which is then metabolised to its active components 5-fluoro-2-deoxyuridine monophosphate (FdUMP) and 5-fluorouridine triphosphate (FUTP). The first inhibits DNA synthesis and cell division by reducing normal thymidine production, and the second inhibits RNA and protein synthesis by competing with uridine triphosphate for incorporation into the RNA strand $(111,112)$.

\section{Acknowledgment}

This article was supported by the Croatian Science Foundation (project no. IP-2018-01-7683) and the Institute for Medical Research and Occupational Health (project no. IMI-IP-2017-2).

\section{Conflict of interests}

None to declare.

\section{REFERENCES}

1. Ghosh AK, Brindisi M. Urea derivatives in modern drug discovery and medicinal chemistry. J Med Chem 2020;63:2751-88. doi: 10.1021/acs.jmedchem.9b01541

2. Chaturvedi $D$. Role of organic carbamates in anticancer drug design. In: Brahmachari $G$, editor. Chemistry and pharmacology of naturally occurring bioactive compounds. $1^{\text {st }}$ ed. Boca Raton (FL): CRC Press; 2013. p. 117-40. doi 10.1201/b13867-6

3. Strzelczyk A, Mann C, Willems LM. Rosenow F, Bauer S Cenobamate for the treatment of focal epilepsies. Expert Opin Pharmacother 2020 . doi : 10.1080/14656566.2020.1803830

4. Keam SJ. Cenobamate: First approval. Drugs 2020;80:73-8. doi: 10.1007/s40265-019-01250-6

5. Adams P, Baron FA. Esters of carbamic acid. Chem Rev 1965;65:567-602. doi: 10.1021/cr60237a002

6. Eddleston M, Clark RF. Insecticides: organic phosphorus compounds and carbamates. In: Hoffman RS, Howland MA, Lewin NA, Nelson LS, editors. Goldfrank's toxicologic emergencies. $9^{\text {th }}$ ed. New York: McGraw-Hill; 2011. p. 1450-60.

7. Chaturvedi D. Perspectives on the synthesis of organic carbamates. Tetrahedron 2012;68:15-45. doi: 10.1016/j. tet.2011.10.001
8. Ghosh AK, Brindisi M. Organic carbamates in drug design and medicinal chemistry. J Med Chem 2015;58:2895-940. doi: $10.1021 / \mathrm{jm} 501371 \mathrm{~s}$

9. DeRuiter J. Amides and related functional groups. Principles of Drug Action 1, 2005 [displayed 20 April 2019]. Available at http://webhome.auburn.edu/ deruija/pda1_amides.pdf

10. Vagner J, Qu H, Hruby VJ. Peptidomimetics, a synthetic tool of drug discovery. Curr Opin Chem Biol 2008;12:292-6. doi: 10.1016/j.cbpa.2008.03.009

11. Karaman R. Prodrugs design based on inter- and intramolecular chemical processes. Chem Biol Drug Des 2013;82:643-68. doi: 10.1111/cbdd. 12224

12. Yılmaz S, Akbaba J, Özgeriş B, Polat Köse L, Göksu S, Gülçin I, Alwasel SH, Supuran CT. Synthesis and inhibitory properties of some carbamates on carbonic anhydrase and acetylcholine esterase. J Enzyme Inhib Med Chem 2016;31:1484-91. doi: 10.3109/14756366.2016.1149477

13. Moraczewski AL, Banaszynski LA, From AM, White CE, Smith BD. Using hydrogen bonding to control carbamate C-N rotamer equilibria. J Org Chem 1998;63:7258-62. doi: 10.1021/j0980644d

14. Kaur D, Sharma P, Bharatam PV. Amide resonance in thioand seleno- carbamates: A theoretical study. J Mol Struct 2005;757:149-53. doi: 10.1016/j.theochem.2005.09.019

15. Deetz MJ, Forbes CC, Jonas M, Malerich JP, Smith BD, Wiest $\mathrm{O}$. Unusually low barrier to carbamate $\mathrm{C}-\mathrm{N}$ rotation. J Org Chem 2002;67:3949-52. doi: 10.1021/jo025554u

16. Jung T, Do HJ, Son J, Song JH, Cha W, Kim YJ, Lee KK, Kwak K. Hindered C-N bond rotation in triazinyl dithiocarbamates. J Mol Struct 2018;1152:215-22. doi: 10.1016/j.molstruc.2017.09.063

17. Dugave C, Demange L. Cis-trans isomerization of organic molecules and biomolecules: implications and applications. Chem Rev 2003;103:2475-532. doi: 10.1021/cr0104375

18. Lauvergnat D, Hiberty PC. Role of conjugation in the stabilities and rotational barriers of formamide and thioformamide. An ab initio valence-bond study. J Am Chem Soc 1997;119:9478-82. doi: 10.1021/ja9639426

19. Marcovici-Mizrahi D, Gottlieb HE, Marks V, Nudelman A. On the stabilization of the syn-rotamer of amino acid carbamate derivatives by hydrogen bonding. J Org Chem 1996;61:8402-6. doi: 10.1021/jo961446u

20. Woolley GA, Jaikaran ASI, Zhang Z, Peng S. Design of regulated ion channels using measurements of cis-trans isomerization in single molecules. J Am Chem Soc 1995;117:4448-54. doi: 10.1021/ja00121a002

21. Vacondio F, Silva C, Mor M, Testa B. Qualitative structuremetabolism relationship in the hydrolysis of carbamates. Drug Metab Rev 2010;42:551-89. doi: 10.3109/03602531003745960

22. Reiner E, Škrinjarić-Špoljar M. Enzimska razgradnja karbamata [Carbamate metabolism, in Croatian]. Arh Hig Rada Toksikol 1968;19:251-8 [displayed 20 March 2019]. Available at https://hrcak.srce.hr/176452

23. Mattarei A, Azzolini M, Zoratti M, Biasutto L, Paradisi C. $\mathrm{N}$-monosubstituted methoxy-oligo(ethylene glycol) carbamate ester prodrugs of resveratrol. Molecules 2015;20:16085-102. doi: 10.3390/molecules200916085

24. Parise Filho R, Polli MC, Garcia M, Barberato-Filho S. Prodrugs available on the Brazilian pharmaceutical market and their corresponding bioactivation pathways. Braz J 
Pharm Sci 2010;46:393-420. doi: 10.1590/S198482502010000300003

25. King AM, Aaron CK. Organophosphate and carbamate poisoning. Emerg Med Clin North Am 2015;33:133-51. doi: 10.1016/j.emc.2014.09.010

26. Maki T, Tsuritani T, Yasukata T. A mild method for the synthesis of carbamateprotected guanidines using the Burgess reagent. Org Lett 2014;16:1868-71. doi: 10.1021/ol5002208

27. Hong JY, Seo UR, Chung YK. Synthesis of carbamates from amines and $N$-tosylhydrazones under atmospheric pressure of carbon dioxide without an external base. Org Chem Front 2016;3:764-7. doi: 10.1039/c6qo00111d

28. Sogorb MA, Vilanova E. Enzymes involved in the detoxification of organophosphorus, carbamate and pyrethroid insecticides through hydrolysis. Toxicol Lett 2002;128:215-28. doi: 10.1016/s0378-4274(01)00543-4

29. Nunes G, Barceló D. Analysis of carbamate insecticides in foodstuffs using chromatography and immunoassay techniques. Trends Anal Chem1999;18:99-107. doi: 10.1016/ S0165-9936(98)00076-4

30. Wang Q, Lemley AT. Competitive degradation and detoxification of carbamate insecticides by membrane anodic fenton treatment. J Agric Food Chem 2003;51:5382-90. doi: 10.1021/jf034311f

31. Plastics Europe. Plastics-the facts 2014/2015. An analysis of European plastics production, demand and waste data [displayed 17 May 2020]. Available at https://www. p l a s t i c s e u rope.org/a p p li cation/ files/5515/1689/9220/2014plastics_the_facts_PubFeb2015. pdf

32. Akindoyo JO, Beg MDH, Ghazali S, Islam MR, Jeyaratnam N, Yuvaray AR. Polyurethane types, synthesis and applications-a review. RSC Adv 2016;6;114453-82. doi: 10.1039/C6RA14525F

33. Pittelkow M, Lewinsky R, Christensen JB. Selective synthesis of carbamate protected polyamines using alkyl phenyl carbonates. Synthesis 2002;15:2195-2202. doi: $10.1055 / \mathrm{s}-2002-34859$

34. Dhanapal D, Rebheka G, Palanivel S, Srinivasan AK. A comparative study on modified epoxy and glycidyl carbamate coatings for corrosion and fouling prevention. Surf Innov 2015;3:127-39. doi: 10.1680/si.13.00025

35. Grube A, Donaldson D, Kiely T, Wu L. Pesticides industry sales and usage 2006 and 2007 market estimates [displayed 15 May 2020]. Availabile at https://www.epa.gov/pesticides/ pesticides-industry-sales-and-usage-2006-and-2007-marketestimates

36. Wharfe J. Historical perspective and overview. In: Thompson KC, Wadhia K, Loibner AP, editors. Environmental toxicity testing. $1^{\text {st }}$ ed. Oxford: Blackwell Publishing Ltd.; 2005. p. $1-32$.

37. Proudfoot A. The early toxicology of physostigmine. Toxicol Rev 2006;25:99-138. doi: 10.2165/00139709-20062502000004

38. Gupta RC. Classification and uses of organophosphates and carbamates. In: Gupta RC, editor. Toxicology of oganophosphate \& carbamate compounds. $1^{\text {st }}$ ed. Waltham (MA): Academic Press; 2006. p. 5-24. doi: 10.1016/b978012088523-7/50003-X

39. Sun B, Straubinger RM, Lovell JF. Current taxane formulations and emerging cabazitaxel delivery systems.
Nano Res 2018;11:5193-218. doi: 10.1007/s12274-0182171-0

40. Avendaño C, Menéndez JC. Anticancer drugs that interact with the DNA minor groove. In: Avendaño C, Menéndez JC, editors. Medicinal chemistry of anticancer drugs. $2^{\text {nd }}$ ed. Elsevier Science, 2015. p. 243-71. doi: 10.1016/B978-0444-62649-3.00006-5

41. Meanwell NA, Belema M. The discovery and development of daclatasvir: an inhibitor of the hepatitis C virus NS5A replication complex. Top Med Chem 2019;32:27-56. doi: $10.1007 / 7355 \quad 2018 \quad 47$

42. Daniel-Mwambete $\overline{\mathrm{K}}$, Torrado S, Cuesta-Bandera C, PonceGordo F, Torrado J. The effect of solubilization on the oral bioavailability of three benzimidazole carbamate drugs. Int J Pharm 2004;272:29-36. doi: 10.1016/j.ijpharm.2003.11.030

43. See S, Ginzburg R. Choosing a skeletal muscle relaxant. Am Fam Physician 2008;78:365-70. PMID: 18711953

44. Kung CH, Kwon CH. Carbamate derivatives of felbamate as potential anticonvulsant agents. Med Chem Res 2009;19:498-513. doi: 10.1007/s00044-009-9208-6

45. Aícua-Rapún I, André P, Rossetti AO, Ryvlin P, Hottinger AF, Decosterd LA, Buclin T, Novy J. Therapeutic drug monitoring of newer antiepileptic drugs: a randomized trial for dosage adjustment. Ann Neurol 2020;87:22-9. doi: 10.1002/ana.25641

46. Flynn S, Babi A. Anticonvulsants. In: Dowd F, Johnson B, Mariotti A, authors. Pharmacology and therapeutics for dentistry. $7^{\text {th }}$ ed. Chapter 12. St. Louis: Elsevier Inc.; 2017. p. 176-92.

47. Rautio J, Meanwell N, Di L, Hageman MJ. The expanding role of prodrugs in contemporary drug design and development. Nat Rev Drug Discov 2018;17:559-87. doi: $10.1038 / \mathrm{nrd} .2018 .46$

48. Ray S, Chaturvedi D. Application of organic carbamates in drug design. Part 1: anticancer agents - recent reports. Drugs Fut 2004;29:343. doi: 10.1358/dof.2004.029.04.787236

49. Kim RY, Yau MC, Galpin JD, Seebohm G, Ahern CA, Pless SA, Kurata HT. Atomic basis for therapeutic activation of neuronal potassium channels. Nat Commun 2015;6:8116. doi: $10.1038 /$ ncomms 9116

50. Montero A, Fossella F, Hortobagyi G, Valero V. Docetaxel for treatment of solid tumours: a systematic review of clinical data. Lancet Oncol 2005;6:229-39. doi: 10.1016/S14702045(05)70094-2

51. Wolkenberg SE, Boger DL. Mechanisms of in situ activation for DNA-targeting antitumor agents. Chem Rev 2002;102:2477-96. doi: 10.1021/cr010046q

52. Verweij J. Docetaxel (Taxotere ${ }^{\mathrm{TM}}$ ): a new anti-cancer drug with promising potential? Br J Cancer 1994;70:183-4. doi: 10.1038/bjc.1994.276

53. Lv Z, Chu Y, Wang Y. HIV protease inhibitors: a review of molecular selectivity and toxicity. HIV AIDS (Auckl) 2015;7:95-104. doi: 10.2147/HIV.S79956

54. Zeldin RK, Petruschke RA. Pharmacological and therapeutic properties of ritonavir-boosted protease inhibitor therapy in HIV-infected patients. J Antimicrob Chemother 2004;53:49. doi: $10.1093 / \mathrm{jac} / \mathrm{dkh} 029$

55. Achenbach CJ, Darn KM, Murphy RL. Atazanavir/ritonavirbased combination antiretroviral therapy for treatment of HIV-1 infection in adults. Future Virol 2011;6:157-77. doi: $10.2217 /$ fvl.10.89 
56. Hull MW, Montaner JS. Ritonavir-boosted protease inhibitors in HIV therapy. Ann Med 2011;43:375-88. doi: 10.3109/07853890.2011.572905

57. Croom KF, Dhilloh S, Keam SJ. Atazanavir: a review of its use in the management of HIV-1 infection. Drugs 2009;69:1107-40. doi: 10.2165/00003495-200969080-00009

58. Ghosh AK, Dawson ZL, Mitsuya H. Darunavir, a conceptually new HIV-1 protease inhibitor for the treatment of drugresistant HIV. Bioorg Med Chem 2007;15:7576-80. doi: 10.1016/j.bmc.2007.09.010

59. Shi LL, Dong J, Ni H, Geng J, Wu T. Felbamate as an add-on therapy for refractory partial epilepsy. Cochrane Database Syst Rev 2017;7(7):CD008295. doi: 10.1002/14651858. CD008295.pub4

60. Glue P, Banfield CR, Perhach JL, Mather GG, Racha JK, Levy RH. Pharmacokinetic interactions with felbamate: In vitro-in vivo correlation. Clin Pharmacokinet 1997;33:214 24. doi: 10.2165/00003088-199733030-00004

61. Swinyard EA, Sofia RD, Kupferberg HJ. Comparative anticonvulsant activity and neurotoxicity of felbmate and four prototype antiepileptic drugs in mice and rats. Epilepsia 1986;27:27-34. doi: 10.1111/j.1528-1157.1986.tb03497.x

62. Rho JM, Donevan SD, Rogawski MA. Barbiturate-like actions of the propanediol dicarbamates felbamate and meprobamate. J Pharmacol Exp Ther 1997;280:1383-91. PMID: 9067327

63. Rho JM, Donevan SD, Rogawski MA. Mechanism of action of the anticonvulsant felbamate: opposing effects on $N$-methyl-D-aspartate and $\gamma$-aminobutyric acid A $_{\text {receptors. }}$ Ann Neurol 1994;35:229-34. doi: 10.1002/ana.410350216

64. Kume A, Greenfield Jr LJ, Macdonald RL, Albin RL. Felbamate inhibits [3H]t-butylbicycloorthobenzoate (TBOB) binding and enhances $\mathrm{Cl}$ - current at the gamma-aminobutyric AcidA (GABAA) receptor. J Pharmacol Exp Ther 1996;277:1784-92. PMID: 8667250

65. Ticku MK, Kamatchi GL, Sofia RD. Effect of anticonvulsant felbamate on $\mathrm{GABA}_{\mathrm{A}}$ receptor system. Epilepsia 1991;32:389-91. doi: 10.1111/j.1528-1157.1991.tb04667.x

66. Wisden W, Laurie UJ, Monyer H, Seeburg PH. The distribution of thirteen GABAA receptor subunit mRNAs in the rat brain. I. Telencephalon, diencephalon, mesencephalon. J Neurosci 1992;12:1040-62. doi: 10.1523/ JNEUROSCI.12-03-01040.1992

67. Porter RJ, Nohria V, Rundfeldt C. Retigabine. Neurotherapeutics 2007;4:149-54. doi: 10.1016/j. nurt.2006.11.012

68. Wuttke TV, Seebohm G, Bail S, Maljevic S, Lerche H. The new anticonvulsant retigabine favors voltage-dependent opening of the $\mathrm{K}_{\mathrm{v}} 7.2$ (KCNQ2) channel by binding to its activation gate. Mol Pharmacol 2005;67:1009-17. doi: 10.1124/mol.104.010793

69. Sharma R, Nakamura M, Neupane C, Jeon BH, Shinc H, Melnick SM, Glenn KJ, Jang IS, Park JB. Positive allosteric modulation of GABA $A_{A}$ receptors by a novel antiepileptic drug cenobamate. Eur J Pharmacol 2020:879:173117. doi: 10.1016/j.ejphar.2020.173117

70. Haake A, Nguyen K, Friedman L, Chakkamparambil B, Grossberg GT. An update on the utility and safety of cholinesterase inhibitors for the treatment of Alzheimer's disease. Expert Opin Drug Saf 2020;19:147-57. doi: $10.1080 / 14740338.2020 .1721456$
71. Giacobini E, editor. Cholinesterases and Cholinesterase Inhibitors. London: Martin Dunitz Ltd; 2000.

72. Bosak A, Katalinić M, Kovarik Z. Cholinesterases: structure, role, and inhibition. Arh Hig Rada Toksikol 2011;62:175-90. doi: 10.2478/10004-1254-62-2011-2107

73. Plata-Salaman CR, Zhao B, Teyman RE. Carbamate compounds for use in preventing or treating neurodegenerative disorders. Unites States Patent Application Publication 2002;US 2002/0165273 A1 [displayed 23 November 2020]. Available at https://patents.google.com/patent/ US20020165273A1/en

74. Darvesh S, Darvesh KV, McDonald RS, Mataija D, Walsh R, Mothana S, Lockridge O, Martin E. Carbamates with differential mechanism of inhibition toward acetylcholinesterase and butyrylcholinesterase. J Med Chem 2008;51:4200-12. doi: 10.1021/jm8002075

75. Prince M, Comas-Herrera A, Knapp M, Guerchet M, Karagiannidou M. World Alzheimer Report 2016: improving helatchare for people living with dementia: coverage, quality and costs now and in the future, Alzheimer's disease International (ADI), 2016 [displayed 23 November 2020]. Availabile at https://www.alz.co.uk/research/ WorldAlzheimerReport2016.pdf

76. Kovacs GG, Adle-Biassette H, Milenkovic I, Cipriani S, van Scheppingen J, Aronica E. Linking pathways in the developing and aging brain with neurodegeneration. Neuroscience 2014;269:152-72. doi: 10.1016/j. neuroscience.2014.03.045

77. Camps P, Muñoz-Torrero D. Cholinergic drugs in pharmacotherapy of Alzheimer's disease. Mini Rev Med Chem 2002;2:11-25. doi: 10.2174/1389557023406638

78. Bitzinger DI, Gruber M, Tummler S, Malsy M, Seyfried T, Weber F, Redel A, Graf BM, Zausig YA. In vivo effects of neostigmine and physostigmine on neutrophil functions and evaluation of acetylcholinesterase and butyrylcholinesterase as inflammatory markers during experimental sepsis in rats. Mediat Inflamm 2019;4:ID8274903. doi: $10.1155 / 2019 / 8274903$

79. Frascogna N. Physostigmine: is there a role for this antidote in pediatric poisonings? Curr Opin Pediatr 2007;19:201-5. doi: 10.1097/MOP.0b013e32802c7be1

80. Trevisani GT, Hyman NH, Church JM. Neostigmine: safe and effective treatment for acute colonic pseudo-obstruction. Dis Colon Rectum 2000;43:599-603. doi: 10.1007/ BF02235569

81. Moghul S, Wikinson D. Use of acetylcholinesterase inhibitors in Alzheimer's disease. Expert Rev Neurother 2001;1:61-9. doi: 10.1586/14737175.1.1.61

82. Kamal MA, Klein P, Luo WM, Li YZ, Holloway HW, Tweedie D, Greig NH. Kinetics of human serum butyrylcholinesterase inhibition by a novel experimental Alzheimer therapeutic, dihydrobenzodioxepine cymserine. Neurochem Res 2008;33;745-53. doi: 10.1007/s11064-0079490-y

83. Yu QS, Holloway HW, Utsuki T, Brossi A, Greig NH. Synthesis of novel phenserine-based-selective inhibitors of butyrylcholinesterase for Alzheimer's disease. J Med Chem 1999;42:1855-61. doi: 10.1021/jm980459s

84. Greig NH, Utsuki T, Ingram DK, Wang Y, Pepeu G, Scali C, Yu Q-S, Mamczarz J, Holloway HW, Giordano T, Chen DM, Furukawa K, Sambamurti K, Brossi A, Lahiri DK. Selective butyrylcholinesterase inhibition elevates brain acetylcholine, 
augments learning and lowers Alzheimer $\beta$-amyloid peptide in rodent. Proc Natl Acad Sci USA 2005;102:17213-8. doi: 10.1073/pnas.0508575102

85. Guo T, Gu H, Hobbs DW, Rokosz LL, Stauffer TM, Jacob B, Clader JW. Design, synthesis, and evaluation of tetrahydroquinoline and pyrrolidine sulfonamide carbamates as $\gamma$-secretase inhibitors. Bioorg Med Chem Lett 2007;17:3010-3. doi: 10.1016/j.bmcl.2007.03.055

86. Kamal MA, Qu X, Yu Q, Tweedie D, Holloway HW, Li Y, Tan Y, Greig NH. Tetrahydrofurobenzofuran cymserine, a potent butyrylcholinesterase inhibitor and experimental Alzheimer drug candidate, enzyme kinetic analysis. J Neural Transm (Vienna) 2008;115:889-98. doi: 10.1007/s00702008-0022-y

87. Alter MJ. Epidemiology of hepatitis $\mathrm{C}$ virus infection. World J Gastroenterol 2007;13:2436-41. doi: 10.3748/wjg.v13. i17.2436

88. Chary A, Holodniy M. Recent advances in hepatitis $\mathrm{C}$ virus treatment: review of $\mathrm{HCV}$ protease inhibitor clinical trials. Rev Recent Clin Trials 2010;5:158-73. doi: $10.2174 / 157488710792007293$

89. Hwang J, Huang L, Cordek DG, Vaughan R, Reynolds SL, Kihara G, Raney KD, Kao CC, Cameron CE. Hepatitis C virus nonstructural protein $5 \mathrm{~A}$ : biochemical characterization of a novel structural class of RNA-binding proteins. J Virol 2010;84:12480-91 doi: 10.1128/JVI.01319-10

90. Shi ST, Polyak SJ, Tu H, Taylor DR, Gretch DR, Lai MM. Hepatitis C virus NS5A colocalizes with the core protein on lipid droplets and interacts with apolipoproteins. Virology 2002;292:198-210. doi: 10.1006/viro.2001.1225

91. Kohler JJ, Nettles JH, Amblard F, Hurwitz SJ, Bassit L, Stanton RA, Ehteshami M, Schinazi RF. Approaches to hepatitis $\mathrm{C}$ treatment and cure using NS5A inhibitors. Infect Drug Resist 2014:7:41-56. doi: 10.2147/IDR.S36247

92. Lee C. Daclatasvir: potential role in hepatitis C. Drug Des Devel Ther 2013;7:1220-33. doi: 10.2147/DDDT.S40310

93. Cada DJ, Kim AP, Baker DE. Elbasvir/Grazoprevir. Hosp Pharm 2016;51:665-86. doi: 10.1310/hpj5108-665

94. Keating GM. Ombitasvir/Paritaprevir/Ritonavir: a review in chronic HCV genotype 4 infection. Drugs 2016;76:1203-11. doi: 10.1007/s40265-016-0612-1

95. Belema M, Nguyen VN, Bachand C, Deon DH, Goodrich JT, James CA, Lavoie R, Lopez OD, Martel A, Romine JL, Ruediger EH, Snyder LB, St Laurent DR, Yang F, Zhu J, Wong HS, Langley DR, Adams SP, Cantor GH, Chimalakonda A, Fura A, Johnson BM, Knipe JO, Parker DD, Santone KS, Fridell RA, Lemm JA, O'Boyle DR, Colonno RJ, Gao M, Meanwell NA, Hamann LG. Hepatitis C virus NS5A replication complex inhibitors: the discovery of daclatasvir. J Med Chem 2014;57:2013-32. doi: 10.1021/jm401836p

96. World Health Organization. World Health Organization model list of essential medicines: 21st list 2019. Geneva: World Health Organization [displayed 8 December 2020]. Available at: https://apps.who.int/iris/handle/10665/325771.

97. O'Doherty DS, Shields CD. Methocarbamol-new agent in treatment of neurological and neuromuscular diseases. J Am Med Assoc 1958;167:160-3. doi: 10.1001/ jama.1958.02990190014003
98. Anthelmintic benzimidazole carbamates [displayed 20 September 2020]. Available at https://patents.google.com/ patent/US4512998A/en

99. Köhler P. The biochemical basis of anthelmintic action and resistance. Int J Parasitol 2001;31:336-45. doi: 10.1016/ s0020-7519(01)00131-x

100. Campbell WC. The chemotherapy of parasitic infections. J Parasitol 1986;72:45-61. doi: 10.2307/3281795

101. Giordani C, Marin GH, Perez D, Soraci A, Errecalde J. Mechanism of action of drugs with activity against multicellular parasites. Parazitologija 2017;51:294-316 [displayed 23 November 2020]. Available at http://sedici. unlp.edu.ar/bitstream/handle/10915/98772/Mechanism_of_ action_of_drugs_with_activity_against_multicellular_ parasites.pdf-PDFA.pdf? sequence $=1$ \&isAllowed $=\mathrm{y}$

102. Rautio J, Kumpulainen H, Heimbach T, Oliyai R, Oh D, Järvinen T, Savolainen J. Prodrugs: design and clinical applications. Nat Rev Drug Discov 2008;7:255-70. doi: $10.1038 / \mathrm{nrd} 2468$

103. Hahn KK, Wolff JJ, Kolaser JM. Pharmacogenetics and irinotecan therapy. Am J Health Syst Pharm 2006;63:22117. doi: $10.2146 /$ ajhp060155

104. Frese S, Diamond B. Structural modification of DNA therapeutic option in SLE. Nat Rev Rheumatol 2011;7:7338. doi: 10.1038/nrrheum.2011.153

105. Mathijessen RH, van Alphen RJ, Verweij J, Loos WJ, Nooter K, Stoter G, Sparreboom A. Clinical pharmacokinetics and metabolism of irinotecan (CPT-11). Clin Cancer Res 2001;7:2182-94. PMID:11489791

106. Sitar DS. Clinical pharmacokinetics of bambuterol. Clin Pharmacokinet 1996;31:246-56. doi: 10.2165/00003088199631040-00002

107. Zhou T, Liu S, Zhao T, Zeng J, He M, Xu B, Qu S, Xu L, Tan W. Chiral analysis of bambuterol, its intermediate and active drug in human plasma by liquid chromatographytandem mass spectrometry: application to a pharmacokinetic study. J Chromatogr B Analyt Technol Biomed Life Sci 2015;997:38-44. doi: 10.1016/j.jchromb.2015.05.024

108. Svensson LA, Tunek A. The design and bioactivation of presystemically stable prodrugs. Drug Metab Rev 1998;19:165-94. doi: 10.3109/03602538809049622

109. Yaltho TC, Ondo WG. The use of gabapentin enacarbil in the treatment of restless legs syndrome. Ther Adv Neurol Disord 2010;3:269-75. doi: 10.1177/1756285610378059

110. Guerreiro C, Albuquerque L, Reimão S. Radiation recall myelitis following capecitabine: first case report. Clin Neurol Neurosurg 2020;196:105978. doi: 10.1016/j. clineuro.2020.105978

111. Terranova-Barberio M, Roca M, Zotti A, Leone A, Bruzzese F, Vitagliano C, Scogliamiglio G, Russo D, D’Angelo G, Franco R, Budillon A, Gennaro E. Valproic acid potentiates the anticancer activity of capecitabine in vitro and in vivo in breast cancer models via induction of thymidine phosphorylase expression. Oncotarget 2016;7:7715-31. doi: 10.18632/ oncotarget. 6802

112. Longley DB, Harkin DP, Johnston PG. 5-Fluorouracil: mechanisms of action and clinical strategies. Nat Rev Cancer 2003;3:330-8. doi: 10.1038/nrc1074 


\section{Karbamatna skupina kao strukturni element lijekova - pregledni rad}

Zbog svoje vrlo dobre kemijske i proteolitičke stabilnosti, sposobnosti prodiranja kroz stanične membrane i sličnosti s peptidnom vezom, derivati karbamata posljednjih godina sve više privlače pozornost medicinskih kemičara i dobivaju važniju ulogu u modernom načinu otkrivanja lijekova. Tako je u današnje vrijeme karbamatna skupina strukturni i funkcionalni element mnogih odobrenih lijekova, a mnogi se već i koriste kao lijekovi za liječenje raznih vrsta bolesti poput raka, epilepsije, hepatitisa C, infekcije HIV-om, Alzheimerove bolesti i mnogih drugih. U lijekovima, karbamatna skupina može biti važan dio molekule koji ima ulogu u interakciji lijek-meta ili je umetnuta u strukturu spoja kako bi se poboljšala biološka aktivnost temeljne molekule. U protulijekovima, karbamatna se skupina koristi uglavnom zbog mogućnosti smanjenja osjetljivosti spoja na metaboličke enzime, odnosno povećanja hidrolitičke stabilnosti samoga spoja. U ovom je radu dan ne samo kratki pregled karbamata koji se koriste kao lijekovi u raznim područjima primjene, kao i karbamata koji se koriste kao protulijekovi, nego i uvid u mehanizam djelovanja nekih od njih.

KLJUČNE RIJEČI: antiepileptici; antikonvulzanti; inhibitori kolinesteraza; inhibitori proteaza; neurodegenerativne bolesti; protulijekovi 